\title{
The Impact of Pre-Service Teachers' Orientation on the Implementation of Inquiry-Based Science Instruction
}

\author{
Ashlie Sizer ${ }^{1}$, Heather Tharp ${ }^{1}$, Jennifer Wrigley ${ }^{1}$, Adel Al-Bataineh ${ }^{1}$, Do-Yong Park ${ }^{1 *}$ \\ 1 Illinois State University, USA
}

Received 23 July $2021 \cdot$ Accepted 5 September 2021

\begin{abstract}
The purpose of the study is to investigate how pre-service elementary teachers' orientation about science inquiry impacts their implementation of inquiry-based instruction. Teaching orientation is one of the levels of pedagogical content knowledge (PCK) which impacts on teachers' instructional practice. With thirty-one pre-service teachers, data are collected using a survey and three vignettes and are analyzed using a correlational coefficient. The results show that (a) there is a moderate relationship between pre-service teachers' view of inquiry-based instruction and their willingness to implement it; (b) pre-service teachers' confidence in implementing inquiry-based instruction increases as they gain experience with inquiry-based methods through coursework; (c) the participants favor using inquiry methods, but they feel more comfortable with a more teachercentered approach. It implies that one science method course may not suffice to produce teachers who are self-efficacious about teaching inquiry-based science. Thus, they need additional instruction to implement a more student-centered inquiry approach.
\end{abstract}

Keywords: preservice teachers, PCK, inquiry-based instruction, teaching orientation

\section{INTRODUCTION}

As the content and pedagogy of inquiry-based instruction continues to evolve, educators are forming new standards and practices to provide more opportunities for students to engage in meaningful learning experiences. The implementation of these practices depends on the teaching orientation toward the pedagogical content knowledge (PCK) of classroombased science instructors.

Since Shulman (1986)' introduction of PCK into general education, there has been much research on the linkage between PCK and science teaching. This research has focused on issues, such as the orientation, development, and assessment of science teachers around the world (Appleton, 2006; Boesdorfer et al., 2014; De Jong et al., 2005; Feyzioglu, 2015; Gess-Newsome, 1999; Hanuscin et al., 2011; Hume \& Berry, 2011; Klaiwong et al., 2011; Kind, 2016; Loughran et al., 2006; Magnusson et al., 1999; van Driel et al., 1998).

While much is known about the impact of science teachers' subject matter knowledge on instruction (GessNewsome, 1999), little is understood about the relationship between inquiry-based instruction and teaching orientation of pedagogical content knowledge. This is important because PCK is not just the delivery of information in a science class; it is a transformation of knowledge to the level of students' understanding (Shulman, 1987). PCK can answer such questions as: What can I do to help my students understand the scientific concepts more effectively? How can I make knowledge more aligned with the level of students' understanding? These are all pertinent to students' reception of scientific knowledge (cf. the transformation of Shulman's pedagogical reasoning model; Shulman, 1987).

The term "orientation" means the teachers' knowledge and beliefs about science teaching, which guides "instructional decisions about issues such as objectives, the content of student assignments, the use of textbooks, and other curriculum materials, and the evaluation of student learning" (Magnusson et al., 1999, p. 97). Simply put, the teacher's orientation impacts his/her instruction.

One of the most effective models for teaching science is the $5 \mathrm{E}$ model: Engagement, Exploration, Explanation,

(c) 2021 by the authors; licensee Modestum. This article is an open access article distributed under the terms and conditions of the Creative Commons Attribution License (http://creativecommons.org/licenses/by/4.0/).

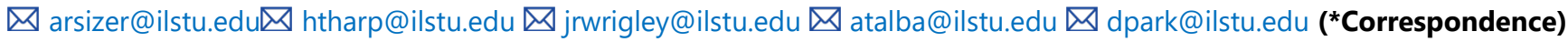




\section{Contribution to the literature}

- To elicit the correlation between pre-service elementary teachers' orientation and implementation of inquiry-based instruction.

- To verify variables that are correlated to the implementation of inquiry-based teaching within pre-service elementary science education.

Elaboration, and Evaluation. Each phase of the model is focused on orienting and asking questions to provoke curiosity, generating hypotheses, planning and researching the experimentation process, analyzing and interpreting results, developing coherent conclusions, and evaluating the given outcome (Zervas et al., 2015, p. 356). The difficult part of implementing inquiry models, such as the $5 \mathrm{E}$, is that pre-service science teachers are not adequately trained in such processes and may lack adequate content knowledge (Lakin \& Wallace, 2015). To remedy this deficiency, teacher education programs should include courses that incorporate inquiry-based instruction in their curriculum.

This study examines how pre-service teachers' teaching orientation impacts their implementation of inquiry-based teaching methods. Inquiry-based teaching often is misunderstood, due to the numerous definitions of "inquiry", the complexity of inquiry-based teaching, and students' abilities to use in the process of inquiry investigation (Chen \& She, 2015; Hofstein \& Lunetta, 2004; NRC, 1996). Although these aspects of misunderstanding and implementation complexity reside in science education, inquiry-based instruction has been a major pillar of science instruction over the decades (Minner et al., 2010).

\section{REVIEW OF LITERATURE}

\section{Inquiry-Based Teaching and Learning}

The National Research Council defined inquiry as "a multifaceted activity that involved making observations; posing questions; examining books and other sources of information to see what is already known; planning investigations; reviewing what is already known in light of experimental evidence; using tools to gather, analyze, and interpret data; proposing answers, explanations, and predictions; and communicating the results" (NRC, 1996, p. 23). Inquiry is, "a teaching strategy that fosters creativity, autonomy, intellectual skepticism, active participation and interaction of students" (McConney et al., 2014, p. 965). However, inquiry is not, as many think, the same as a "hands-on activity" in terms of the level of complexity, methods, goals, specific characteristics, and the nature of science. While hands-on activities are vital in science education, inquiry takes these activities to the next level by requiring students to create their own knowledge and construct their own ideas and conclusions. As such, inquiry as defined contains many facets of science teaching and scientific investigation.
Yet, the main goal of inquiry is to develop a reasonable explanation for the existence of a phenomenon. This is accomplished in a four-step process: organizing knowledge, generating a hypothesis, seeking evidence to test the hypothesis, and finally constructing an argument (Windschitl, 2008).

The process of learning that is created with inquirybased teaching can take on different shapes (Herron, 1971). Specifically, there are four types of inquiry commonly used in education: confirmation inquiry, structured inquiry, guided inquiry, and open inquiry. Confirmation inquiry is found in most science classrooms; it generally is used to reinforce previously introduced material. Structured inquiry requires that students develop explanations about a particular topic. Guided inquiry requires that the students develop their own research, based on a prompt posed by the teacher. The most student-centered form of inquiry is open inquiry. Open inquiry allows students to ask questions and develop their own plausible conclusions (Bell et al., 2005; McConney et al., 2014).

It has been well documented that the student outcomes of inquiry-based teaching methods are worth the time and effort it may take educators to become familiar with the process. Marshall and Alston (2014), for example, implemented a professional development program to facilitate their study of inquiry-based teaching methods. They examined whether inquirybased teaching methods would increase student scores on Measures of Academic Progress tests. The study found that, when compared to non-participating teachers in the same 11 districts, the teachers who taught using inquiry-based teaching methods had higher performing students. Walan and Rundgren (2015) added that inquiry-based teaching methods not only have the ability to increase student test scores, but also increase student interest in learning.

\section{Pedagogical Content Knowledge and Science Teaching Orientations}

Schulman (1987) introduced the concept of pedagogical content knowledge (PCK) as the distinctive body of knowledge needed for teaching, which, in turn, refers to teacher's interpretations of subject matter knowledge for facilitating student learning. He went on to explain that PCK "represents the blending of content and pedagogy into an understanding of how particular topics, problems, or issues are organized, represented, 
and adapted to the diverse interests and abilities of learners, and presented for instruction" (p. 8).

Magnusson et al. (1999) theorized that pedagogical content knowledge for science teaching is comprised of four categories: knowledge of science curricula, knowledge of students' understanding of science, knowledge of instructional strategies, and knowledge of ways to assess scientific literacy. Knowledge of science curricula includes science courses, goals and objectives, while knowledge of students' understanding of science incorporates the requirements for learning and areas of student difficulty. Knowledge of instructional strategies requires an understanding of science-specific approaches encompassing representations and activities, whereas knowledge of assessment of scientific literacy integrates the assessable methods and dimensions of science learning. They stated that PCK impacts science teaching orientation the most (Magnusson et al., 1999).

Because of the ambiguity created by the multiple definitions of PCK, Friedrichsen et al. (2011) examined the teaching orientation component of the Magnusson et al. (1999) PCK model for science teaching. The authors identified the methodological problems such as "(a) using orientations in different or unclear ways, (b) unclear or absent relationship between orientations and the other model components, (c) simply assigning teachers to one of nine categories of orientations, and (d) ignoring the overarching orientation component" (p. 358). Based on this work, Friedrichsen et al. (2011) defined science teaching orientations as a set of beliefs with the following dimensions: (a) goals and purposes of science teaching, (b) views of the nature of science, and (c) beliefs about science teaching and learning. They suggested, therefore, that there should be a "need for conceptual and methodological clarity concerning the role of science teaching orientations" (p. 372).

\section{Pre-service Teachers' Teaching Orientation on Inquiry-based Teaching}

The exposure of pre-service teachers receive to inquiry-based learning can impact their use of inquiry techniques in the classroom (NRC, 2000). Magnusson et al. (1999) stated that "the practical value of pedagogical content knowledge as a construct has to do with its potential to define important dimensions of expertise in science teaching that can guide the focus and design of pre-service and in-service teacher education programs" (p. 116). Therefore, teacher educators must provide opportunities for pre-service science teachers to explore, elaborate, and incorporate new information and conclusions about teaching science into their existing knowledge and beliefs.

Feyzioglu (2015) set out to determine the pedagogical orientation of pre-service teachers toward inquiry. The purpose was to analyze the relationship between facilitation of inquiry and pedagogical orientations. He found that many pre-service teachers believe that they cannot successfully implement an inquiry-based approach in the classroom because they do not possess an adequate understanding of inquiry-based methods (Feyzioglu, 2015). Lee and Shea (2016) studied how preservice elementary teachers view inquiry-based teaching. The research was driven by the concern that, if elementary teachers have low confidence in their ability to teach science, they will avoid teaching the subject altogether. This program only required the teacher candidates to complete two natural science courses. Each of the participants was enrolled in a science methods course taught by the same instructor (Lee \& Shea, 2016). Lee and Shea (2016) concluded that the participants' attitudes and confidence in teaching inquiry-based science improved throughout the semester.

There is a correlation between teaching orientation and the implementation of inquiry-based teaching methods, but this connection is complex and still open for debate. Two studies reveal the lack of clarity. First, Miranda and Damico (2015) examined a professional development model combining a summer Research Experience for Teachers (RET) and an academic yearlong Professional Learning Community (PLC). The goal was to determine how the program would impact the teachers' beliefs about inquiry-based instruction and their classroom practices. The study concluded that the combination of RET and PLC professional development can change teachers' beliefs about their classroom orientations. Second, Pilitsis and Duncan (2012) studied how pre-service teachers' belief orientations changed as they progressed through their science methods courses. The study took place over a two-year period conducting multiple inquiry-based activities. The results showed that all of the pre-service teachers shifted their orientations and became more student-centered in teaching and activities, which is necessary for inquirybased learning. The authors asserted that this change in belief orientations is attributed to the participants' overall content-knowledge, as well as to their interpretations of the activities (Pilitsis \& Duncan, 2012).

These two studies add to our understanding of the correlation between use of inquiry-based methods in the classroom and pedagogical content knowledge. However, there is still much to be learned in terms of the impact of specific variables, such as teachers' confidence level, the number of inquiry courses taken in their college years, and their belief orientation about inquirybased science. Thus, this study aims to fill that gap by focusing on pre-service teachers' perceptions about the implementation of inquiry-based teaching methods in relation to their teaching belief orientation. The following questions guided this study:

1. What is the correlation between pre-service teachers' orientation and implementation of inquiry-based instruction? 
2. What variables are correlated to the implementation of inquiry-based teaching?

\section{METHOD}

\section{Research Design}

This study basically employed a quantitative approach although we used a code to identify the patterns of preservice teachers' belief orientation. We also used a correlational design to examine the influence of teaching orientation on the implementation of inquiry-based science instruction by pre-service elementary teachers after being exposed to a science methods course, without an embedded clinical experience (Creswell, 2003).

\section{Instruments and Measures}

The data for this study were collected using a survey and a vignette. The instrument used in this study was constructed to determine the correlation between teaching orientation and inquiry-based teaching methods for the study population of preservice elementary science teachers.

Survey. The measures of this construct consisted of the responses of the participants on seven survey items that were designed to serve as indicators of the teachers' belief orientation about their inquiry-based science teaching. The survey was developed specifically for this study based on a review of empirical research on teacher belief orientation about inquiry-based science instruction (e.g., Cobern et al., 2014; Friedrichsen et al., 2011; Kind, 2016; Pilitsis \& Duncan, 2012). The survey items were scored on a 5-point Likert scale. The Cronbach's coefficient alpha of internal consistency reliability of the scores was 0.631 , which is an adequate level of measurement accuracy for the purpose of this study.

Vignettes. Additionally, researchers used three vignettes that required the participants to evaluate teaching scenarios. The vignettes for this questionnaire were adapted from the Pedagogy of Science Teaching Test (POSTT) (Cobern et al., 2014), which provides science teaching orientation profiles across four teaching styles. The styles are didactic direct, active direct, guided inquiry, and open inquiry. The participant's feelings on implementing inquiry-based teaching are addressed by the vignettes (Appendix). The questionnaire included multiple choices questions regarding inquiry and content knowledge, and incorporated vignettes, which allowed participants to gain an understanding of the four inquiry teaching modes. Figure 1 shows the spectrum of the four instructional modes.

Decreased inquiry instruction mode $\leftarrow$ Didactic direct ---------- Active direct

Figure 1. Instructional modes and teaching orientations
Cobern et al. (2014) described the four teaching orientations: Didactic direct (DD) is the pedagogical orientation in which teacher "presents and explains science content directly... illustrates with example or demo. No student activities." Active direct (AD) orientations are teacher-centered, as the teacher "presents and explains science content directly...students actively engage in verification/confirmation." Guided inquiry (GI) is the inquiry orientation, requiring students to "actively explore phenomenon or idea with teacher guidance toward desired science content." Lastly, open inquiry (OI) is the most inclusive type of inquiry, in which the students actively explore phenomenon or idea they choose ... teacher facilitate process but does not prescribe" (p. 2270). In summary, in the DD and AD teaching orientations, science is presented as factual knowledge, which is 'ready-made-science,' while in the GI and OI teaching modes, science is developed by process of scientific inquiry, which is 'science-in-themaking.'

In the study, we chose three vignettes from POSTT (one from each discipline of biology, physical science, and earth science). This is pertinent to preservice teachers' science teaching orientation profiles as they completed teaching activities of those three subject areas in their science method course.

\section{Participants and Research Setting}

We used a purposeful sampling design to select participants for this study (Patton, 2014). Participants in this study were thirty-one pre-service elementary science teachers $(\mathrm{N}=31)$. They were enrolled in a science methods course, which is a requirement of their teacher education program. This was a nonrandom convenience sample, as they were volunteers, willing and available to participate in the study (Patton, 2014).

\section{Description of Science Method Course}

As Friedrichsen et al. (2011) suggested, we designed science method course by embedding, "beliefs about the goals or purposes of science teaching, beliefs about the nature of science, and beliefs about science teaching and learning" (p. 373). During this course, participants had no chance to have student teaching experience (or clinical experience) in the science classrooms. Instead, participants had a micro-teaching opportunity in which they taught one inquiry-based instruction as a group by using one topic of subject knowledge one in each of life sciences, physical sciences, and change of seasons. They discussed what inquiry means; inquiry-based instruction with methods and strategies; constructivism and self-efficacy as learning theories; pedagogical

$\rightarrow$ Increased inquiry instruction mode Guided inquiry ------------ Open inquiry 
content knowledge (PCK), including orientations, beliefs, and teaching repertoires toward science instruction, the nature of science (NOS) to help pupils to learn science; and how to assess pupils' science learning. Finally, the components of the course were integrated in 13 different experiments, including STEM education focusing on engineering design. They also created two inquiry lesson plans and conducted a semester-long group inquiry science project practicing the process of scientific inquiry in an authentic environment.

\section{Data Collection and Analysis}

Data were collected from the following two sources and analyzed as a summative assessment.

Survey. The survey was conducted at the end of the semester. Answers were presented in the form of a fivepoint Likert scale with 1 being "strongly agree" and 5 being "strongly disagree." Data were analyzed in two ways (Miles et al., 2014). First, descriptive statistics from the survey were compiled into a data table. Second, researchers conducted a correlational analysis using Pearson's correlation coefficient $(r)$. This reveals statistical significance in the survey results as a way of measuring strength and direction of a relationship between teaching orientation and the implementation of inquiry-based instruction.

The correlation coefficient $(r)$ is difficult to interpret due to its slightly different implications in various disciplines. In education, labeling systems, also used in this paper, accept that the correlation coefficients of $r=0.30$ to 0.70 generally are considered as modest positive correlations, and $r=0.70$ to 0.90 as strong positive correlations. The coefficient of determination is more meaningful when it is obtained by squaring the correlation coefficient $r$ (Taylor, 1990). In this study, the coefficient of determination $\left(r^{2}\right)$ is defined as the percentage of how one variable can be explained by the other variable. Therefore, researchers interpreted the coefficient of determination in each correlation value by using the percentage.

Vignettes. Participants were asked to consider three different classroom scenarios, one each in biology, physical science, and earth and space. They were asked to choose one out of four answers. The responses were analyzed using descriptive statistics. Two researchers individually read and re-read the vignettes until they identified a unit of data, defined as "any meaningful (or potentially meaningful) segment of data" (Merriam, 1998, p. 179), by comparing to the survey results. The first researcher is a member of the secondary education faculty, and the second is a member of the science education faculty at a well-respected teacher education program at a public university in the midwestern United States.

The commonalities in participants' responses to three vignettes were used as the basis of data analysis. First, the two researchers created emergent codes after they individually read each participant's responses to vignettes. They coded each response in one of the four categories of inquiry orientation: (a) active direct inquiry, (b) guided inquiry, (c) open inquiry, and (d) didactic direct orientation. Researchers determined the number of preservice teachers in each category to identify the most common responses, which gave an overall picture of the participants' orientation. The two researchers individually cross-checked each participant's responses over the three vignettes to find the patterns of orientation. They then compared this to the individual's survey response to confirm how belief orientations are related to inquiry-based instruction. The two coders discussed their selections following multiple individual readings of the participants' responses until they came to a consensus based on evidence found in both survey and vignettes. The inter-coder reliability was found to be $87.65 \%$, which was considered to be high.

\section{RESULTS}

The purpose of this study was to ascertain how prepared pre-service elementary teachers believed themselves to be to use inquiry-based teaching methods in the classroom, and to identify key areas of confidence about implementing inquiry-based teaching methods. The participants' demographic information is as follows. Ranging in age from 20 to $26,70 \%$ identified as female $(\mathrm{N}=22)$ and $30 \%$ as male $(\mathrm{N}=9)$. The majority $(87.09 \%$; $\mathrm{N}=27$ ) had taken only one science inquiry course and only four participants $(12.91 \% ; \mathrm{N}=4)$ had taken two inquiry science courses.

\section{Research Question 1: What is the Correlation between Pre-service Teachers' Orientation and Implementation of Inquiry-based Approach in Teaching?}

Table 1 showed that, overall, the respondents felt somewhat confident about teaching science, having a mean score of 2.48 on a five-point scale with 1 being highest confidence. It also showed that the participants felt strongly about plans to implement an inquiry-based approach in their future classrooms, with a mean score of 1.74. Additionally, the pre-service teachers were very motivated to learn more about inquiry-based teaching, with a mean score of 1.58 on a five-point Likert scale with 1 being "strongly agree" and 5 being "strongly disagree." It can be concluded that the pre-service teachers feel confident about teaching science, implementing an inquiry-based method, and are interested in learning more about this pedagogical approach. 
Table 1. PCK and implementation of inquiry

\begin{tabular}{|c|c|c|c|c|}
\hline Category & Mean & edi & rd De & Variance \\
\hline I am confident about teaching science & 2.48 & 2 & 1.03 & 1.06 \\
\hline I plan to use inquiry in my classroom & 1.74 & 2 & 0.68 & 0.47 \\
\hline I would like to learn more about inquiry-based teaching & 1.58 & 1 & 0.77 & 0.59 \\
\hline $\begin{array}{l}\text { I am hesitant to implement inquiry-based learning because my content } \\
\text { knowledge is insufficient }\end{array}$ & 3.26 & 3 & 1.03 & 1.06 \\
\hline $\begin{array}{l}\text { I am hesitant to implement inquiry-based learning because my pedagogical } \\
\text { content knowledge is insufficient }\end{array}$ & 2.90 & 3 & 1.01 & 1.02 \\
\hline I find it hard to implement inquiry-based lessons & 2.97 & 3 & 0.85 & 0.72 \\
\hline I understand inquiry-based teaching and methods and could teach about it & 2.81 & 3 & 1.05 & 1.10 \\
\hline
\end{tabular}

Table 2. Correlation coefficient among variables

\begin{tabular}{llcccc}
\hline & A & B & C & D & E \\
\hline A & 1 & -.43 & .11 & .20 & -.37 \\
B & & 1 & -.26 & $-.55^{*}$ & $.45^{*}$ \\
C & & 1 & .38 & -.41 \\
D & & & 1 & -.15 \\
E & & & & 1 \\
\hline
\end{tabular}

$(d f=29 ; * \mathrm{P}<0.01)$

A: Number of inquiry courses taken

B: Confident to teach inquiry

C: Hesitant to implement inquiry due to content

D: Hesitant to implement inquiry due to PCK

E: Understand inquiry-based instructional strategies

\section{Research Question 2: What Variables are Correlated to the Implementation of Inquiry-teaching?}

Survey: Participants were asked whether they were reluctant to implement inquiry-based methods due to insufficient content knowledge and/or insufficient pedagogical content. The participants gave a neutral response (mean score 3.26) to having insufficient content knowledge (as shown in Table 1). We conducted a correlation analysis to determine whether inquiry methods course had an impact on participants' confidence in implementing inquiry due to content knowledge. As shown in Table 2, there was a weak correlation between these two variables, with a correlation coefficient of $r=0.11$ and an $r^{2}$ value of 0.01 , revealing a $1.2 \%$ shared variance.

Participants reported a closer to neutral response regarding their hesitation to implement inquiry due to insufficient pedagogical content knowledge, with a mean score of 2.90 (see Table 1), and a correlation coefficient of 0.20 (see Table 1), which implies a weak correlation between the number of inquiry courses taken and willingness to implement inquiry-based instruction on pedagogical content knowledge, with a shared variance of $4.1 \%$. Regarding the questions on the difficulty of implementing inquiry-based lessons and how well they understood and could teach using this approach to science instruction, the participants reported a neutral response with a mean score of 2.97 and 2.81 respectively (see Table 1). However, in relation to PCK, participants' responses showed a modest inverse correlation of -0.55 (shared variance of $30.6 \%$ ) between participants' understanding of pedagogical content knowledge and confidence in teaching inquiry (see Table 2).

Vignettes: In the final portion of the survey, participants were given three classroom scenarios one each from biology, physical science, and earth science (Appendix), to examine their teaching orientation profiles. As shown in Table 3, the most popular orientation was the active direct inquiry (AD) method, mentioned by $37.63 \%$ of the participants. The second highest inquiry orientation was the guided inquiry (GI) mode, mentioned by $31.81 \%$ of the participants. The third highest inquiry orientation was open inquiry (OI), selected by $22.58 \%$ of participants. The remaining $8.6 \%$ selected the didactic direct orientation (DD).

As seen in Table 3, this particular preservice elementary teacher group preferred the active didactic orientation to the didactive direct. As shown in Table 3, there was a modest positive correlation (0.45) between the two variables of teaching inquiry and personal understanding of inquiry-based teaching. This suggests that, when the participants are confident about teaching inquiry, they better understand the instructional strategies it requires. As a result, they prefer it as a teaching method. The modest inverse correlation was between the ability to teach inquiry and the participants' understanding of pedagogical content knowledge ($0.55)$, which indicates that the participants' belief about their ability to teach inquiry and their understanding of PCK are not positively correlated, but not necessarily in a causal relationship. 
Table 3. Participant response to inquiry-based learning scenarios

\begin{tabular}{lccccc}
\hline Inquiry Category & Vignette 1 & Vignette 2 & Vignette 3 & $\begin{array}{c}\text { Total number of } \\
\text { responses }\end{array}$ & $\begin{array}{c}\text { Participant } \\
\text { preference (\%) }\end{array}$ \\
\hline Didactic Direct & 2 & 1 & 5 & 8 & $8.60 \%$ \\
Active Direct & 7 & 18 & 10 & 35 & $37.63 \%$ \\
Guided Inquiry & 13 & 4 & 12 & 29 & $31.81 \%$ \\
Open Inquiry & 9 & 8 & 4 & 21 & $22.58 \%$ \\
Total number of responses & 31 & 31 & 31 & 93 & $100 \%$ \\
\hline
\end{tabular}

\section{DISCUSSION}

The first research question of this study asked how pre-service teachers' orientations impact their willingness to implement inquiry-based teaching methods in their classrooms. When looking directly at correlations between teaching orientation and implementation of inquiry-based teaching, the results showed a weak correlation. It should be noted that there might be a stronger correlation with a larger sample size, as the small sample size in this study may have impacted the correlation results.

Our second research question related to the variables connected to implementation of inquiry-based teaching. The results of the study reported a weak correlation between the number of inquiry courses taken and the participants' willingness to implement inquiry-based approach to learn content knowledge $(r=.11)$. The weak correlation may be due to the limitations of the study, as we can only infer that, as preservice teachers learn more about this approach to teaching through inquiry courses, they improved their understanding of inquiry. But they were less likely to follow through with implementation, when faced with the complexity of inquiry-based teaching, especially when figuring out how to manage the classroom, develop experimental materials, and prepare assessments, based on their understanding of the Nature of Science (NOS). To some extent, this is similar to the finding of Pilitsis and Duncan (2012). They found that, although all pre-service teachers progressed toward employing more student-centered, inquirybased teaching methods, their orientation might change depending on the subject and course materials.

Additionally, this study asked the participants to analyze three vignettes and to select which orientation they would implement given similar circumstances in a future science classroom. The inquiry strategies ranged from didactic direct to open inquiry, with the mode of the distribution being active direct. According to the POSTT (Cobern et al., 2014), open inquiry is the most inclusive (and consequently most student-centered) type of inquiry, as students are generating and carrying out their own investigations.

Only $22.58 \%$ of the responses selected orientations consistent with open inquiry methods, signifying that it is not a highly popular teaching orientation for preservice elementary science teachers. This is most likely due to the lack of confidence with inquiry teaching at the undergraduate level. Lee and Shea (2016) reached a similar conclusion when studying how pre-service elementary teachers view inquiry-based teaching. Background research presented in the study claimed that $90 \%$ of pre-service teachers, enrolled in an elementary education course, had never used openinquiry teaching (Lee \& Shea, 2016), which might explain their orientation. However, their attitudes toward and confidence in teaching inquiry-based science improved by taking a science method course throughout the semester. The study noted a significant change $(p<0.5)$ in perception of inquiry (Lee \& Shea, 2016).

In addition, the fact that $22.58 \%$ of the respondents selected open inquiry contrasted with Feyzioglu's (2015) research findings that pre-service teachers' pedagogical approach never reached the open inquiry level. Feyzioglu hypothesized that this might be due to the limited educational experiences of the pre-service teachers, and a lack of knowledge and skills to put an inquiry model into practice in the classroom. The low number may have resulted from the timing of survey, in that it was administered before the full semester of student teaching experiences that may have provided opportunities to practice inquiry-based methods in real classrooms. Furthermore, all participants of our study were situated before clinical experiences that provide an opportunity to practice inquiry-based method in real classrooms.

Most of the participants in our study opted for either guided inquiry approaches, or active direct approaches. Guided inquiry (31.81\%) was the second highest inquiry orientation. This orientation requires students to develop and carry out their own investigations, but at the prompting of the instructor. The participants who selected guided inquiry orientations felt confident in allowing students to investigate concepts for themselves, as long as the teacher provided the research question. Participants who selected active direct orientations are more teacher-centered than those who selected guided inquiry methods, but they do allow students to actively participate and engage in confirmation investigations. The majority of the pre-service teachers in this study selected an active direct method (37.63\%), illustrating their willingness to involve students in the learning process, but they were reluctant to give up formalized instruction, wanting to control, rather than facilitate, the lesson. 
Didactic direct $(8.60 \%)$ is the lowest pedagogical orientation, as shown in Table 3. Here the lesson is highly teacher-centered. In a didactic direct method of teaching, the instructor presents or explains a concept completely, with no student involvement in the process. Actually, research has shown this to be the least ideal method of teaching and learning (Cobern et al., 2004). When dealing with those who have little understanding about the scope and depth of inquiry and inquiry-based teaching, this result seems natural because of the complexity of inquiry. As shown in Table 1, the majority of participants $(87.09 \%)$ had taken only one inquiryrelated course. This implies that one inquiry science method course may not suffice to produce teachers who are highly knowledgeable and self-efficacious about teaching inquiry-based science.

Regarding the relationship between confidence in teaching inquiry and a personal understanding of inquiry-based teaching, we found a modest correlation between these two variables. Therefore, we were able to confirm that there was a positive relationship between overall knowledge of inquiry and the pre-service teachers' confidence in using this approach. In conjunction with the correlational data, the vignette responses received in this study depicted a range of preservice teachers' orientations from didactic direct to open inquiry, including a variety of orientation preferences within the participants' own pedagogy. In other words, pre-service teachers' orientations moved toward inquiry-based teaching methods, but their orientations were subject to change, depending on the course materials used in their teacher education program (Pilitsis \& Duncan, 2012). This could suggest that discussions in inquiry-based learning courses, based on situations similar to the vignettes, could help students comprehend and value different approaches to inquirybased learning.

\section{LIMITATIONS AND FURTHER STUDY}

Due to the small sample size with only one survey given in one location, the results of this study may be skewed toward the orientation of a specific group of preservice teachers. Thus, we recommend that further studies be conducted, perhaps following a particular class of students over their four-year program to see how their orientations about inquiry would change over time. The other limitation was that, in this situation, the preservice teachers could not implement inquiry-based teaching in real classrooms, as their clinical experience occurred after the study. New studies would offer insights on how preservice teachers' orientations may impact their implementation of inquiry-based instruction. Such studies would reveal how orientations shift or get refined through the pre-service teachers' clinical experience, as they implement inquiry-based science instruction in real classrooms over the four years of the teacher education program. At the same time, future studies also would show which parts of a methods course students believed promoted an increase in confidence and alignment to an inquiry based orientation.

\section{CONCLUSION}

This study sought to obtain insights on the relationship between pre-service teachers' orientations and their confidence in and willingness to implement inquiry-based teaching methods in the science classroom. The results of the survey revealed that there is a neutral to moderate relationship between how preservice teachers view inquiry-based teaching and their inclination to employ this approach as instructors. Overall, participants in this study were eager to learn more about inquiry-based methods, and plan on utilizing inquiry in their future classrooms. The data illustrated that, as participants gained knowledge of inquiry-based teaching techniques, they became more confident that they could use this method successfully. However, the orientation vignette data revealed that the participants favored more teacher-directed approaches, such as active-direct. This suggests that pre-service teachers are not completely knowledgeable about student-centered forms of learning, such as open inquiry; so, that they would need more practical experiences in real classroom settings.

Possibly due to the aforementioned limitations of this study, researchers detected only a weak relationship between pre-service elementary science teachers' confidence and willingness to engage in inquiry-based instruction and their teaching orientation toward this approach. In other words, pre-service teachers understand how science should be taught using inquirybased instruction, but they may not be ready to implement it. More extensive training and more student teaching practice in inquiry orientations during their teacher education program may be necessary to adequately prepare pre-service teachers to implement more student-centered inquiry strategies in the classroom.

Author contributions: All authors have sufficiently contributed to the study, and agreed with the results and conclusions.

Funding: No funding source is reported for this study.

Declaration of interest: No conflict of interest is declared by authors.

\section{REFERENCES}

Appleton, K. (2006). Science pedagogical content knowledge and elementary school teachers. In $\mathrm{K}$. Appleton (Ed.), Elementary science teacher education: International perspectives on contemporary issues and practice (pp. 31-54). Lawrence Erlbaum Associates.

Bell, R.L., Smetana, L., \& Binns, I. (2005). Simplifying inquiry instruction. The Science Teacher 72(7), 30-33. 
Boesdorfer, S. B., \& Lorsbach, A. (2014). PCK in action: Examining one chemistry teacher's practice through the lens of her orientation toward science teaching. International Journal of Science Education, 36(13), 2111-2132. https://doi.org/10.1080/ 09500693.2014 .909959

Chen, C., \& She, H. (2015). The effectiveness of scientific inquiry with/without integration of scientific reasoning. International Journal of Science and Mathematics Education, 13(1), 1-20.

Cobern, W., Schuster, D. G., Adams, B., Skjold, B. A., Zeynep, E. M., Bentz, A., \& Sparks, K. (2014). Pedagogy of science teaching tests: Formative assessments of science teaching orientations. International Journal of Science Education, 36(13), 2265-2288.

https:/ / doi.org/10.1080/09500693.2014.918672

Creswell, J. (2003). Research design: Qualitative, quantitative, and mixed methods approaches. Sage Publications.

De Jong, O., Van Driel, J. H., \& Verloop, N. (2005). Preservice teachers' pedagogical content knowledge of using practice models in teaching chemistry. Journal of Research in Science Teaching, 42(8), 947-964. https://doi.org/10.1002/tea.20078

Feyzioglu, E. Y. (2015). Pre-service science teachers' pedagogical orientations of science inquiry continuum. Batı Anadolu Eğitim Bilimleri Dergisi, 6, 1-36. http://webb.deu.edu.tr/baed/giris/baed/ 11_1.pdf

Friedrichsen, P. M., Driel, J. H., \& Abell, S. K. (2011). Taking a look at science teaching orientations. Science Education, 95, 358-376. https://doi.org/ $10.1002 /$ sce. 20428

Gess-Newsome, J. (1999). Secondary teachers' knowledge and beliefs about subject matter and their impact on instruction. In J. Gess-Newsome, \& N. G. Lederman (Eds.), Examining pedagogical content knowledge: The construct and its implications for science education (pp. 95-132). Kluwer Academic Publishers.

Hanuscin, D. L., Lee, M. H., \& Akerson, V. L. (2011). Elementary teachers' pedagogical content knowledge for teaching the nature of science. Science Education, 95(1), 145-167. https:/ / doi.org/10.1002/sce.20404

Herron, M. D. (1971). The nature of scientific enquiry. School Review, 79, 171-212. https://doi.org/ 10.1086/442968

Hofstein, A., \& Lunetta, V. N. (2004). The laboratory in science education: Foundations for the twenty-first century. Science Education, 88, 28-54. https:/ / doi.org/10.1002/sce.10106

Hume, A., \& Berry, A. (2011). Constructing CoRes-a strategy for building PCK in pre-service science teacher education. Research in Science Education, 41, 341-355. https://doi.org/10.1007/s11165-0109168-3

Kind, V. (2016). Preservice science teachers' science teaching orientation and beliefs about science. Science Education, 100(1), 122-152. https:/ / doi.org/ 10.1002/sce. 21194

Klaiwong, K., Hewson, M. G., \& Praphairaksit, N. (2011). Identifying pedagogical content knowledge (PCK) in an undergraduate inquiry-based biology laboratory program. The International Journal of Learning, 17(12), 17-30. https://doi.org/10.18848/ 1447-9494/CGP/v17i12/47367

Lakin, J., \& Wallace, C.S. (2015). Assessing teachers' use of inquiry methods in the middle school science classroom. Journal of Science Teacher Education, 26(2), 139-162. https://doi.org/10.1007/s10972-0149412-1

Lee, C. K., \& Shea, M. (2016). An analysis of pre-service elementary teachers' understanding of inquirybased science teaching. Science Education International, 27(2), 217-237.

Loughran, J., Berry, A., \& Mulhall, P. (2006). Understanding and developing science teachers' pedagogical content knowledge. Sense Publishers. https:/ / doi.org/10.1163/9789087903657

Magnusson, S., Krajcik, J., \& Borko, H. (1999). Nature, sources, and development of pedagogical content knowledge for science teaching. In J. GessNewsome, \& N. G. Lederman (Eds.), Examining pedagogical content knowledge: The construct and its implications for science education (pp. 95-132). Kluwer Academic Publishers. https://doi.org/10.1007/0306-47217-1_4

Marshall, J. M., \& Alston, D. (2014). Effective, Sustained Inquiry-Based Instruction Promotes Higher Science Proficiency Among All Groups: A 5-Year Analysis. Journal of Science Teacher Education, 25(7), 807-821. https://doi.org/10.1007/s10972-014-9401-4

McConney, A., Oliver, M., Woods-McConney, A., Schibeci, R., \& Maor, D. (2014). Inquiry, engagement, and literacy in science: A retrospective cross-national analysis using PISA 2006. Science Education, 98(6), 963-980. https:// doi.org/10.1002/sce.21135

Merriam, S. B. (1998). Qualitative research and case study applications in education. Jossey-Bass Publishers.

Miles, M. B., Huberman, A. M., \& Saldana, J. (2014). Qualitative data analysis: A methods sourcebook. Sage Publications. Arizona State University Press.

Minner, D. D., Levy, A. J., \& Century, J. (2010). Inquirybased science instruction - What is it and does it matter? Results from a research synthesis years 1984 to 2002. Journal of Research in Science Teaching, 47(4), 474-496. https:/ / doi.org/10.1002/tea.20347 
Miranda, R. R., \& Damico, J. B. (2015). Changes in teachers' beliefs and classroom practices concerning inquiry-based instruction following a year-long RET-PLC program. Science Educator, 24(1), 23-35.

National Research Council. (1996). National science education standards. National Academy Press.

National Research Council. (2000). Inquiry and the national science education standards: A guide to teaching and learning. National Academy Press.

Patton, M. Q. (2014). Qualitative research and evaluation methods: Integrating theory and practice (4th ed.). Sage Publications.

Pilitsis, V., \& Duncan, R. G. (2012). Changes in belief orientations of preservice teachers and their relation to inquiry activities. Journal of Science Teacher Education, 23(8), 909-936. https: / / doi.org/10.1007/s10972-012-9303-2

Shulman, L. S. (1986). Those who understand; Knowledge growth in teaching. Educational Researcher, 15(2), 4-14. https://doi.org/10.3102/ 0013189X015002004

Shulman, L. S. (1987). Knowledge and teaching; Foundations of the new reform. Harvard Educational Review, 57(1), 1-22. https://doi.org/10.17763/ haer.57.1.j463w79r56455411
Taylor, R. (1990). Interpretation of the correlation coefficient: A basic review. Journal of Diagnostic Medical Sonography, 6(1), 35-39. https:/ / doi.org/10.1177/875647939000600106

van Driel, J. H., Verloop, N., \& De Vos, W. (1998).Developing science teachers' pedagogical content knowledge. Journal of Research in Science Teaching, 33(6), 673-695. https://doi.org/10.1002/ (SICI)1098-2736(199808)35:6<673::AIDTEA5>3.0.CO;2-J

Walan, S., \& Rundgren, S.C. (2015). Student responses to a context- and inquiry-based three-step teaching model. Teaching Science, 61(2), 33-39.

Windschitl, M. (2008). What is Inquiry? A framework for thinking about authentic scientific practice in the classroom. In J. Luft, R. Bell, \& J. Gess-Newsome (Eds.), Science as Inquiry in the Secondary Setting (pp. 1-10). NSTA Press.

Zervas, P., Sotirius, S., Tiemann, R., \& Sampson, D. (2015). Assessing problem solving competence through inquiry-based teaching in school science education [Paper presentation]. 12th International Conference on Cognition and Exploratory Learning in Digital Age (pp. 355-358). http:/ / files.eric.ed.gov/fulltext /ED562155.pdf 


\section{APPENDIX}

\section{Pedagogical Content Knowledge in Relation to Inquiry}

Instruction: The purpose of this instrument is to understand how you understand the relationship between pedagogical content knowledge (PCK) and inquiry-based instruction as a result of this science method course. PCK we define is your knowledge and beliefs about how to transform science subject knowledge to the level of students' understanding, which usually includes your knowledge of science curriculum, assessment, instructional strategies, and students' understanding of science. The following vignettes are describing a different teacher's teaching profile/type/mode. There are four different teachers' teaching profiles (or types or modes) in each vignette.

Please read each of the following vignettes carefully and evaluate how you might teach this lesson in a similar situation in your future classroom.

\section{Scenario 1}

Mrs. Adams (Pseudoname) class is studying about bacteria. She tells her students that it is important to wash our hands before eating because there are bacteria present, even though we cannot see them. Mrs. Adams explains that, although we cannot see one bacterium with the naked eye, thousands more bacteria can grow in one place until a colony becomes visible. She demonstrates this by showing students the bacterial colonies that grew on some agar plates she had inoculated several days previously. She finishes the lesson with a reminder to wash your hands throughout the day.

Thinking about how you would teach this lesson, of the following, which one is most similar to what you would likely do?

A. I would begin by giving students fresh agar plates to inoculate and having them observe the plates over several days. I would end with a class discussion about what they learned from their observations and how it relates to being healthy.

B. I would begin and end the lesson the same as Mrs. Adams. However, rather than showing them plates with bacteria already on them, I would allow students to touch their fingers onto their own fresh agar plates and then make observations over several days.

C. I would begin by having a class discussion on why it is important to wash our hands. Then I would have students touch their fingers onto their own fresh agar plates and make observations over several days. We would finish the lesson by relating student observations to the importance of hand washing.

D. I would conduct this lesson in a similar way to Mrs. Adams.

\section{Scenario 2}

Ms. Dunker (Pseudoname) has her Kindergarten students gather around a small pool she has filled with water. She has a set of 10 objects of different sizes, different shapes, and different materials; some which will sink and some which will float. Ms. Dunker's goal is for her students to first distinguish the objects by whether they sink or float, and then realize that this does not depend on the size of the object but on what it is made of.

Thinking of how you would teach this lesson, of the following, what would you most likely do?

A. Drop objects one by one into the water, and have the children notice that some sink and some float. Point out that all the stones sank, no matter how big or small, and all the wooden blocks floated, etc. Conclude by stating the lesson objective, that it is not size that matters but the material the object is made of.

B. Have students come by one by one and drop an object into the water, with everyone calling out whether it sank or floated. Ask them to suggest what this depended on; when some suggest size and others what it is made of, have them test these ideas by dropping more objects. Then have them agree on a conclusion.

C. Have all the students drop various objects in the water and seeing what happens. Then have them talk among themselves about this and ask volunteers to give their ideas about it, with others saying if they agreed or not.

D. Have students come one by one and drop an object into the water, with everyone calling out whether it sank or floated. Point out that all the stones sank, no matter how big or small, and all the wooden blocks 
floated, etc. Conclude with the lesson objective, that it is not size that matters but the material the object is made of.

\section{Scenario 3}

Ms. Williams' (Pseudoname) 6th grade class is learning about how fossils can provide evidence of how life has changed over time. She poses the question: "How do fossils help show us changes on Earth over time?" She continues by asking the students to examine several different rock samples, all containing different types of fossils.

Thinking of how you would teach this lesson, of the following, how would you evaluate this lesson so far?

A. The students are asked to make observations before being instructed on what to look for. Instead, Ms. Williams' should have described how fossils provide evidence of change over time, using the fossil samples as examples to demonstrate her point.

B. The students are asked to make observations before being instructed on what to look for. Instead, Ms. Williams' should have described how fossils provide evidence of change over time, and then have the students examine the different rock samples to verify Ms. Williams' explanation.

C. This lesson is fine the way it is. Ms. Williams' states a question for the students to think about and then provides materials the students can utilize to explore this question.

D. Ms. Williams' should have not posed such a detailed question prior to student investigations. The students should have been allowed to examine the rock samples and, as a class, discussed their ideas about the fossils.

\section{http://www.ejmste.com}

